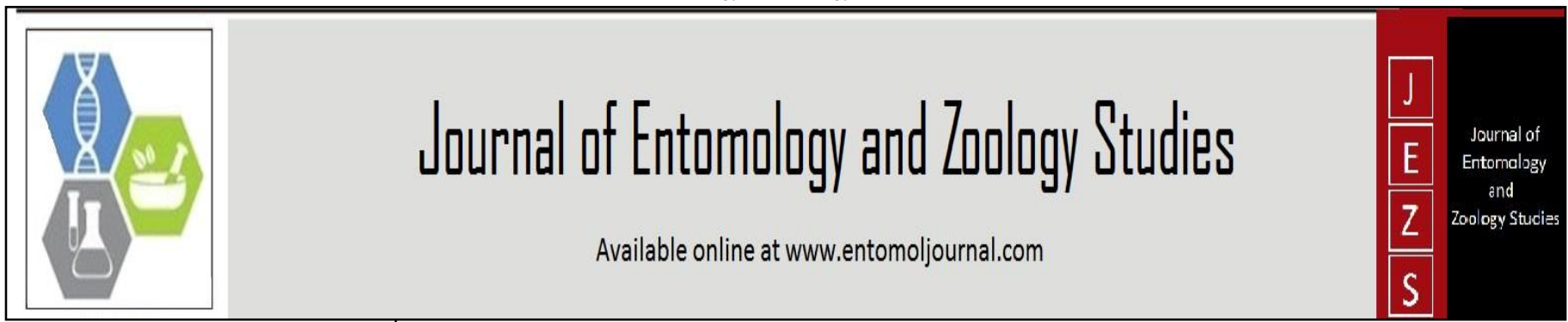

E-ISSN: 2320-7078

P-ISSN: 2349-6800

www.entomoljournal.com

JEZS 2021; 9(4): 346-347

(C) $2021 \mathrm{JEZS}$

Received: 07-05-2021

Accepted: 09-06-2021

\section{Kamalu S Kuma}

MVSc Scholar, Department of

Veterinary Clinical medicine,

Ethics and Jurisprudence,

College of Veterinary and Animal

Sciences, Mannuthy, Thrissur,

Kerala, India

\section{Ambily VR}

Assistant Professor, Department of Veterinary Clinical medicine,

Ethics and Jurisprudence,

College of Veterinary and Animal

Sciences, Mannuthy, Thrissur,

Kerala, India

Usha Narayana Pillai

Professor and Head, Department of Veterinary Clinical medicine,

Ethics and Jurisprudence,

College of Veterinary and Animal

Sciences, Mannuthy, Thrissur,

Kerala, India
Corresponding Author:

Kamalu S Kumar

MVSc Scholar, Department of

Veterinary Clinical medicine,

Ethics and Jurisprudence,

College of Veterinary and Animal

Sciences, Mannuthy, Thrissur,

Kerala, India

\section{Therapeutic efficacy of topical selamectin in feline otoacariosis}

\section{Kamalu S Kumar, Ambily VR and Usha Narayana Pillai}

DOI: https://doi.org/10.22271/j.ento.2021.v9.i4e.8793

\section{Abstract}

Otodectes cynotis (ear mite) is a psoroptid mite that accounts for $50-80 \%$ of otitis externa cases in cats. A 9 year old female cat was presented with history of intense aural irritation, scratching at the ears and presence of brown waxy exudates from the external ear canal. Diagnosis is made with microscopic examination of ear wax, revealing the presence of the Otodectes cynotis. The cat was treated with selamectin spot-on preparation at $6 \mathrm{mg} / \mathrm{kg}$ body weight, as single dose applied topically in a single spot at the base of the neck region infront of the scapulae. A single administration of a spot-on formulation of selamectin at the minimum dose was found to be efficient in the treatment of ear mite infestations in the present case.

Keywords: cat, otitis externa, Otodectes cynotis, selamectin

\section{Introduction}

Otoacariosis or otodectic mange is diagnosed in up to $66 \%$ of the otitis externa cases reported in cats (Becskei et al., 2017) ${ }^{[1]}$ Otodectes cynotis is a relatively large mite $(0.3-0.4 \mathrm{~mm})$ that lives mostly in the ear canal of the dog and cat and also it can be found occasionally on other areas of the body, especially around the tail base on cats where they sleep curled up. It is a non-burrowing mite and it lives by browsing on surface skin debris and tissue fluid. Otodectes infection leads to the production of copious amount of dry, dark brown, crumbly waxy debris resembling coffee grounds (Paterson, 2012) ${ }^{[2]}$. Diagnosis of O.cynotis infestation is confirmed by visualization of live mites with otoscopic examination or by microscopic examination of swab samples from the ear canals (Yang and Huang, 2016) ${ }^{[3]}$.

\section{Case history and observations}

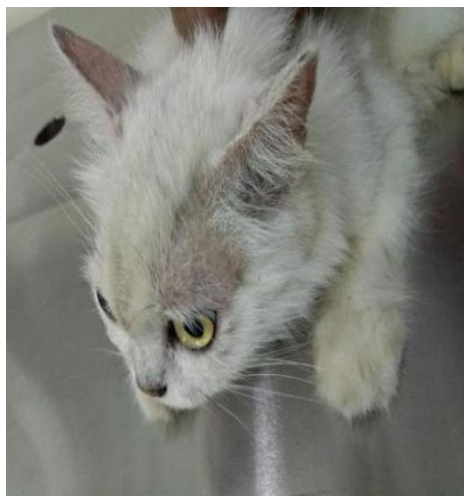

Fig 1: Alopecia around the base of the ears, forehead and ear pinna 


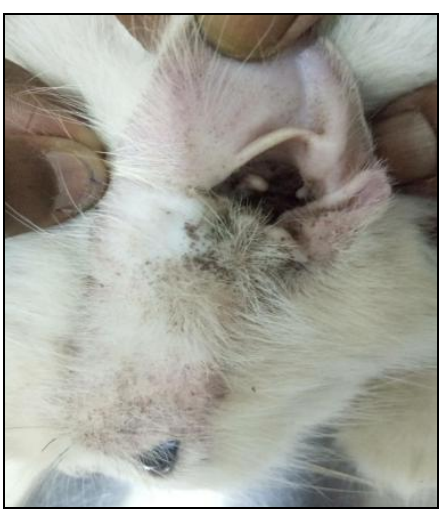

Fig 2: Dry dark brown waxy debris in the external ear canal

A 9 year old female cat was presented with history of brown waxy exudates from the external ear canal, intense aural irritation and scratching at the ears since one month. Clinical examination revealed alopecia around the base of the ears, forehead and ear pinna (Fig.1), presence of dry dark brown waxy debris in the external ear canal (Fig.2).

\section{Diagnosis, Treatment and Discussion}

Microscopic examination of ear swab revealed Otodectes cynotis (Fig.3). Single dose of selamectin spot-on was applied topically at the base of the neck in front of the scapulae at a dosage of $6 \mathrm{mg} / \mathrm{kg}$ (Blot et al., 2003) ${ }^{[4]}$. The animal found to be negative for Otodectes cynotis infestation one month after selamectin application (Fig.4).

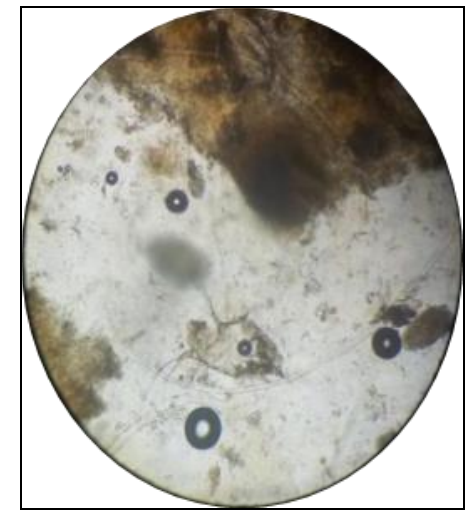

Fig 3: Otodectes cynotis on microscopic examination of ear

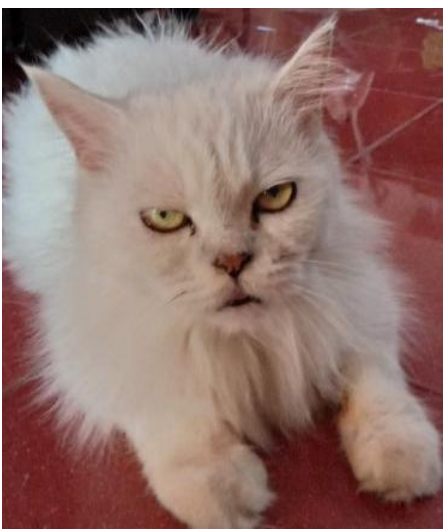

Fig 4: Recovery after 1 month

The case study deals with the treatment of otoacariosis with spot-on formulation of selamectin. Otoacariosis or aural infestation of Otodectes cyanotis is a relatively common disease found in cats. Selamectin, which is a new acaricide macrocyclic lactone is active against otodectic mange in cats, fleas in dogs and cats, sarcoptic mange in dogs, biting lices in dogs and cats, heartworms in dogs and cats, intestinal ascarids in dogs and cats and hookworms in cats. A single topical administration of selamectin at the minimum recommended dose is found to be effective against naturally acquired aural infestations of $O$. cynotis mites in cats (Blot et al., 2003) ${ }^{[4]}$.

\section{Conclusion}

Single topical application of selamectin spot-on when provided at the minimum recommended dosage of $6 \mathrm{mg} / \mathrm{kg}$ was found to be effective against $O$. cynotis mites in cats when assessed 30 days after administration with a disappearance of mites and clinical signs. It was found safe and convenient to apply.

\section{Acknowledgement}

Authors are thankful for the staffs of Teaching Veterinary Clinical Complex, College of Veterinary and Animal Sciences, Mannuthy for the facilities provided.

\section{References}

1. Becskei C, Reinemeyer C, King VL, Lin D, Myers MR, Vatta AF. Efficacy of a new spot-on formulation of selamectin plus sarolaner in the treatment of Otodectes cynotis in cats. Veterinary parasitology 2017;238:S27S30.

2. Paterson S, Tobias K. Atlas of ear diseases of the dog and cat. John Wiley \& Sons 2012,184.

3. Yang C, Huang HP. Evidence-based veterinary dermatology: a review of published studies of treatments for Otodectes cynotis (ear mite) infestation in cats. Veterinary dermatology 2016;27(4):221-e56.

4. Blot C, Kodjo A, Reynaud MC, Bourdoiseau G. Efficacy of selamectin administered topically in the treatment of feline otoacariosis. Veterinary parasitology 2003;112(3):241-247. 